Historia Slavorum Occidentis

2021, nr 2 (29)

ISSN 2084-1213

DOI: $10.15804 /$ hso2 10208

Ryszard TOMCZYK (SZCZECin)

ORCID: 0000-0002-8490-9013

\title{
Cmentarze w Dawidowie koło Lwowa. Polskie dziedzictwo narodowe
}

Keywords: cemeteries, history of Poles in the Eastern Borderlands of the old Polish Republic, Dawidów near Lvov, Polish national heritage

Abstract: Cemeteries are important sources of knowledge of the local and regional social history. Historical objects of sepulchral art (graves, tombs) located in cemeteries, with preserved inscriptions and epitaphs, represent also important source material for genealogical research. The article is an attempt at presenting past events and names of Poles who lived in Dawidów near Lvov, based on old and new gravestones and other source materials (lately recreated by the settlers' descendants).

\section{Wprowadzenie}

Poza obszarem metropolitalnym Lwowa, za Pasiekami Zubrzyckimi, po prawej stronie ruchliwej drogi ze Lwowa do Bóbrki, w dolinie i na pagórkach, rozciąga się zabudowa Dawidowa. Miejscowość dzieli się na starą i nową. Starą część przecina rzeczka Dawidówka i linia kolejowa biegnąca ze Lwowa w kierunku Chodorowa i dalej do Czerniowiec. Dominuje tu parterowa zabudowa jednorodzinna. Na wzgórzu stoi widoczna z daleka cerkiew greckokatolicka św. Bogurodzicy. W przeszłości był to kościół rzymskokatolicki św. Stanisława. Świątynia zachowała swoją dawną bryłę z niewielką ośmioboczną wieżyczką. Po drugiej stronie torów kolejowych, za rzeką Dawidówką jest mała cerkiew św. Męczennika Dymitra. Na wzgórzach, bliżej Lwowa, wzdłuż drogi do Bóbrki rozciąga się nowa część Dawidowa, powstała po drugiej wojnie światowej. 
Jest tutaj osiedle wielopiętrowych bloków. Wśród nich, na wprost parku im. Tarasa Szewczenki, gdzie stoi jego pomnik oraz budynek szkoły i inne obiekty użyteczności publicznej, znajduje się nowa, duża cerkiew prawosławna św. Apostołów Piotra i Pawła.

Dawidów ma długą i burzliwą historię. Król Kazimierz Wielki w 1355 r. nadał wieś za zasługi Grzegorzowi Tymszycowi, który w ziemi lwowskiej posiadał już kilka wsi. Oficjalne potwierdzenie praw majątkowych do Dawidowa otrzymał jego syn Stanisław z Dawidowa (Dawidowski), starosta samborski i sędzia ziemi lwowskiej w dokumencie z 20 III 1355 r. Stanisław z Dawidowa w 1410 r. kupił także wieś Czerepin od Jędrzeja Czuryły ze Stojanic. Na mocy przywileju króla Władysława Jagiełły z 1415 r. Stanisław Dawidowski osiedlał ludność w Dawidowie na prawie magdeburskim. Przywilej osadniczy został ograniczony tylko dla ludności katolickiej, niemniej wieś w tym czasie legitymowała się zarówno polską, jak i ruską antroponimią kmiecią ${ }^{1}$. Wówczas też Dawidowski uzyskał takie prawo w odniesieniu do swoich dóbr ziemskich w Nowosielcach. Bogobojny właściciel wsi w 1413 r. podarował także grunt i dom we Lwowie konwentowi oo. dominikanów². W 1439 r. ufundował parafię i rzymskokatolicki kościół parafialny w Dawidowie 3 . W 1447 r. sąd ziemski we Lwowie poświadczył, że Jan Dawidowski oddał w zastaw Maciejowi Mańkowi miejscowy staw z prawem łowienia ryb, aż do spłaty 16 grzywien długu 4 . W XV w. we wsi funkcjonowała także karczma. Wieś była w posiadaniu rodziny Dawidowskich, która pieczętowała się herbem Prus II, do połowy XVII w. Na początku XX w. lwowski badacz pochodzenia żydowskiego Majer Bałaban podał, że z przedmieścia Lwowa do Dawidowa w XVI w. przenieśli się Karaimi. Informacja ta weszła do obiegu naukowego, chociaż współcześnie jest kwestionowana ${ }^{5}$. W średniowieczu i okresie nowożytnym wieś była niszczona podczas najazdów Tatarów, Turków i Kozaków, a następnie odbudowywana. Ważną rolę w rozwoju Dawidowa odegrali

1 A. Janeczek, Polska ekspansja osadnicza w ziemi lwowskiej w XIV i XV w., Przegląd Historyczny 4 (1978), s. 606; tenże, Exceptis schismaticis. Upośledzenie Rusinów w przywilejach prawa niemieckiego Wtadystawa Jagietty, Przegląd Historyczny 3 (1984), s. 537.

2 Wcześniej, w 1399 r. król Władysław Jagiełło nadał lwowskim oo. dominikanom posiadłość w Krotoszynie, położonym obok Dawidowa. Dodatek tygodniowy nr 8, Gazeta Lwowska, 20 II $1858, \mathrm{nr} 41$.

3 Ziemia lwowska za rząów polskich $w$ XIV $i$ XV wieku, we względzie społecznych stosunków rozpoznana przez Aleksandra hr. Stadnickiego, t. III, Lwów 1863, s. 25, 34, 43.

4 Dodatek tygodniowy nr 15, Gazeta Lwowska, 10 IV 1858, nr 81.

5 Zob.: M. Pawelec, Czy Karaimi mieszkali niegdyś w Dawidowie?, Awazymyz. Pismo historyczno-społeczno-kulturalne Karaimów 2 (2014), s. 9-13. 
lwowscy oo. dominikanie. Wieś należała do nich od 1649 r. Zakonnicy ze Lwowa wydzierżawiali miejscowy dwór, zabudowania gospodarcze, pola i łąki. Zachowany do czasów obecnych dwór o cechach klasycystycznych został wybudowany w XIX w. Był użytkowany przez rodziny dzierżawiące folwark. Wokół dworu zachował się stary drzewostan, stanowiący fragment dawnego założenia parkowego. Zachowany do czasów współczesnych budynek dworski wymagał w 2020 r. poważnego remontu. W okresie zaboru austriackiego administratorzy posiadłości ziemskiej w Dawidowie się zmieniali. Wśród dzierżawców tego majątku byli m.in.: w pierwszych dziesięcioleciach XIX w. Jan Brzoszniowski ze Lwowa, w końcu zaś tego wieku Stanisław Popiel z Przemyśla ${ }^{6}$. Prawdopodobnie po jego tragicznej śmierci w 1897 r. majątkiem zarządzał Henryk Müller z Zimnej Wody. Na początku II Rzeczypospolitej majątek ziemski w Dawidowie dzierżawił Henryk Kintzi ${ }^{7}$. Ostatnim zarządcą folwarku w Dawidowie przed wybuchem drugiej wojny światowej był inżynier Franciszek Brzozowski. Duża własność ziemska na terenie Dawidowa pozostała w rękach oo. dominikanów do upadku II Rzeczypospolitej. Poza dobrami w Dawidowie konwent gospodarował także w okolicznych: Kopiatyniu, Czerepiniu i Grabowcu ${ }^{8}$. W pobli-

6 Stanisław Popiel zarządca dóbr oo. dominikanów w Dawidowie został zamordowany 11 III 1897 r. podczas wyborów do Rady Państwa w Wiedniu przez mieszkańców wsi. Wzburzenie mieszkańców wsi spowodowało wcześniejsze zabicie Michała Daćko. Trumnę z ciałem Stanisława Popiela 14 III 1897 r. przy licznym udziale krewnych i znajomych zabitego przewieziono do stacji kolejowej w Sichowie w asyście oddziału huzarów i komisarza starostwa powiatowego. Ciało zostało przewiezione do Przemyśla, gdzie spoczęło w grobowcu rodzinnym. Ojciec Stanisława Władysław Popiel, właściciel dóbr z Przemyśla, pod wpływem silnych przeżyć z powodu śmierci syna zmarł 30 III 1897 r. Na przełomie maja i czerwca 1897 r. toczył się we Lwowie proces chłopów z Dawidowa oskarżonych o zabójstwo Stanisława Popiela. Przed sądem stanęli Polacy i Ukraińcy, m.in.: Wawrzyniec Grab, Ilko Jurkiewicz, Mikołaj Jurkiewicz, Piotr Loster, Jan Najda, Wasyl Nakonieczny, Stefan Stecko, Jan Szeremeta, Jan Telega, Bernard Tokarski, Wojciech Rybczyński. Postępowanie sądowe było relacjonowane w prasie lwowskiej. Kronika, Gazeta Lwowska, 17 III 1897, nr 61; Mord w Dawidowie, Słowo Polskie, 17 III 1897, nr 62; + Wtadystaw Popiel, tamże, 1 IV 1897, nr 74; Proces dawidowski, tamże, 29 V 1897, nr 124; tamże, 1 VI 1897, nr 125; tamże, 1 VI 1897, nr 126; tamże, 2 VI 1897, nr 126; tamże, 4 VI 1897, nr 129; tamże, 5 VI 1897, nr 130.

7 Henryk Kintzi wszedł do zarządu powstałego 15 VII 1919 r. Chrześcijańskiego Związku Dzierżawców Południowo-Wschodnich Kresów Polski. Organizacja dzierżawców miała reprezentować interesy tej rolniczej grupy zawodowej. Zrzeszała dzierżawców narodowości polskiej. Walne zebranie Chrześcijańskiego Związku Dzierżawców pot.-wsch. kresów Polsk, Gazeta Lwowska, 22 VII 1919, nr 167.

8 J. Bigo, Najnowszy skorowidz wszystkich miejscowości z przysiótkami w Królestwie Galicyi, Wielkiem Księstwie Krakowskiem i Księstwie Bukowińskiem z uwzględnieniem wszystkich dotąd zaszłych zmian terytoryalnych kraju, Lwów 1914, s. 32. 
skich Gańczarach na początku XX w. majątek ziemski dzierżawił Władysław Haszlakiewicz Gotlieb, w latach dwudziestych zaś po początek lat trzydziestych XX w. Joanna Mahl. Ostatnim przed wybuchem drugiej wojny światowej zarządcą majątku w Gańczarach był Wincenty Gródecki. Rolnicy z Dawidowa i Gańczar w XIX po połowę XX w. dostarczali płody rolne, mięso i mleko na targ do Lwowa9.

W okresie zaboru austriackiego w Dawidowie na mocy rozporządzenia lwowskiego Gubernium z 4 IV 1845 r. pod patronatem konwentu oo. dominikanów została założona szkoła ludowa. W latach pięćdziesiątych i sześćdziesiątych XIX w. nauczycielem był w niej Sebastian Rossiek, dozorcą zaś włościanin Jan Jarosz. W 1864 r. do szkoły uczęszczało 67 miejscowych dzieci ( 38 chłopców i 29 dziewczynek) ${ }^{10}$. W końcu XIX w. we wsi działała trzyklasowa szkoła ludowa. W 1900 r. jej kierownikiem (nauczycielem kierującym) był Józef Bińkowski ${ }^{11}$. Szkoła w Dawidowie na początku XX w. jako jedyna w Galicji uczyła wiejskie dziewczęta wyrobu sztucznych kwiatów i wieńców pogrzebowych. W 1911 r. członkowie zarządu, wówczas już szkoły im. Marii Konopnickiej w Dawidowie, zwracali się do prezydenta Lwowa o zakup przez Miejski Zakład Pogrzebowy wieńców pogrzebowych, które do tej pory były zamawiane w innych częściach monarchii habsburskiej. Lwowski zakład pogrzebowy potrzebowal wówczas od 40 do 50 wieńców tygodniowo. Wieńce wykonane w szkole w Dawidowie były sprzedawane w lokalu Ligi Pomocy Przemysłowej we Lwowie ${ }^{12}$. W Dawidowie w $1898 \mathrm{r}$. powstała jedna z pierwszych na ziemi lwowskiej Czytelni Towarzystwa Szkoły Ludowej. Miejscowa czytelnia na początku działalności miała 453 książki i otrzymywała cztery czasopisma. W 1898 r. we wsi było zarejestrowanych 22 czytelników ${ }^{13}$.

W Dawidowie w pierwszej połowie XIX w. funkcjonowal punkt pocztowy. W 1830 r. pocztmistrzem był Antoni Ostrowski. Niemniej dopiero w 1870 r. został

9 Urząd Targowy królewskiego miasta Lwowa m.in. w pierwszej połowie kwietnia 1858 r. ukarał dwóch dostawców mleka z Dawidowa za dodawanie do niego wody. Wówczas też taki proceder uprawiali dostawcy mleka z Grzybowic, Lesienic, Obroszyna, Rzęsnej Polskiej, Kozielnik, Kulparkowa, Zboisk czy Zniesienia. Kronika, Gazeta Lwowska, 20 IV 1858, nr 89; tamże, 18 V 1858, nr 112.

10 Szematyzm Szkót Ludowych zostających pod nadzorem Lwowskiego Konsystorza Metropolitalnego Obrzadku Łacińskiego na rok 1864, Lwów 1864, s. 13.

11 Szematyzm Królestwa Galicji i Lodomerii z Wielkim Księstwem Krakowskim, Lwów 1900, s. 553 .

12 Kronika, Goniec, 1 II 1911, nr 1211; tamże, 20 X 1911, nr 1425.

13 K. Rędziński, Akademickie Koło Towarzystwa Szkoły Ludowej we Lwowie (1898-1914), Prace Naukowe Akademii im. Jana Długosza w Częstochowie, Pedagogika 1 (2017), s. 276. 
utworzony urząd pocztowy, który w ruchu listowym i przesyłek wartościowych był połączony z pocztą we Lwowie. Obsługiwał poza Dawidowem także Czerepin, Gańczary, Krotoszyn, Milatycze, Pasieki Zubrzyckie, Siedliska, Tołczów (Tołszczów) i Żyrawkę. W okresie autonomii Galicji w Dawidowie funkcjonowała gmina wiejska. We wsi istniała gminna kasa pożyczkowa i wspierana przez władze gminne Ochotnicza Straż Pożarna. Stan taki trwał do czasów II Rzeczypospolitej. W wyniku reformy administracyjnej Polski 1 VIII 1934 r. została utworzona duża gmina Dawidów. Tworzyły ją dotychczasowe małe gminy i obszary dworskie Czerepin, Dawidów, Kozielniki, Krotoszyn, Pasieki Zubrzyckie, Sichów, Siedliska, Tołszczów, Zubrza. Wieś Gańczary znalazła się w gminie Czyszki. W czasie okupacji niemieckiej przeprowadzono nową reformę administracyjną, w wyniku której część obszaru gminy Dawidów znalazła się w granicach utworzonej gminy Milatycze.

W parafii rzymskokatolickiej św. Stanisława w Dawidowie, którą ufundował Stanisław Dawidowski 6 XI 1439 r., pierwotnie został postawiony kościół drewniany. Potomkowie Stanisława wybudowali około 1600 r. na wzgórzu we wsi nowy kościół murowany w stylu, który łączył cechy późnogotyckie i renesansowe ${ }^{14}$. Nie jest wykluczone, że zgodnie z dawnym zwyczajem budowy świątyń został wzniesiony w miejscu lub obok starego kościoła drewnianego. Na początku XVIII w. świątynia miała trzy ołtarze, a w 1741 r. było ich pięć. Z kolei w 1762 r. ponownie w kościele były trzy ołtarze. Arcybiskup lwowski Hieronim Sierakowski w 1774 r. dokonał konsekracji kościoła w Dawidowie ${ }^{15}$. Obok świątyni w okresie posługi duszpasterskiej ks. Michała Baściaka (1911-1926) została wzniesiona parawanowa murowana dzwonnica na trzy dzwony. Dzwony odlane we lwowskiej firmie Rudolfa Matheisela (+8 III 1933) zostały zawieszone w 1924 r. ${ }^{16}$ W latach 1932-1937 kościół został wyremontowany i rozbudowany. Wcześniej przed kościołem wierni ustawili na wysokim cokole figurę Matki Bożej. Na cokole umieszczono napis „O Maryio bez grzechu

14 G. Rąkowski, Ziemia Lwowska. Przewodnik krajoznawczo-turystyczny po Ukrainie Zachodniej, cz. III, Pruszków 2007, s. 348.

15 D. Zielonka, Parafia św. Stanistawa - szkic rysu historycznego, dawidow-lwow.blogspot. com/2015/07 [dostęp: 10 VII 2019].

16 Napis na mniejszym dzwonie, w środkowej części płaszcza: „Matka Boska Różańcowa za macierzyńską opiekę nad nami wskrzeszenie Ojczyzny za Cud nad Wisłą oswobodzenie od wrogów Małopolskich granic i Lwowa Królowo Korony Polskiej składa Ci ten dzwon w ofierze parafia Dawidów. Dawidów 1924 r.” Na plaszczu większego dzwona napis brzmi: „Najświętsze Serce Pana Jezusa za pięćsetletnie wśród nas królowanie Twoje Boże Serce za przetrwanie długich lat niewoli za ratunek $\mathrm{w}$ dniach niedoli z Twoich darów Tobie Wiekuisty Boże składa tę ofiarę parafia Dawidów 1924 r.” 
poczęta módl się za nami”. Współcześnie pomalowana na biało figura Matki Bożej nadal tam stoi. Zachował się także napis. Parafia św. Stanisława w Dawidowie w XIX i w pierwszej połowie XX w. należała do dekanatu w Szczercu. Do parafii należeli także wyznawcy obrządku rzymskokatolickiego z pobliskich Gańczar i Czerepinia.

Do czasów ekspatriacji po drugiej wojnie światowej zdecydowaną większość mieszkańców Dawidowa stanowili Polacy obrządku rzymskokatolickiego. Także pobliskie Gańczary w większości zamieszkiwali Polacy. Ukraińcy obrządku greckokatolickiego z Dawidowa i Gańczar należeli do parafii w sąsiednim Czerepiniu, gdzie większość mieszkańców stanowili Rusini/Ukraińcy. W Dawidowie mieszkały także rodziny żydowskie ${ }^{17}$, łącznie w 1880 r. Dawidów liczył 1317 mieszkańców. Zgodnie z danymi kościelnymi w 1879 r., gdy parafią administrował ks. Marcin Fijałkowski, we wsi było 1075 wyznawców obrządku rzymskokatolickiego. Wówczas w rejestrach kościelnych wyznawców obrządku rzymskokatolickiego z Gańczar było 230, z Czerepinia zaś 34 ${ }^{18}$. W 1904 r. w Dawidowie z pobliskimi przysiółkami mieszkało 2014 osób, w Gańczarach zaś 298 osób ${ }^{19}$. W II Rzeczypospolitej, w 1936 r., gdy proboszczem był ks. Stanisław Sadowski w Dawidowie było 2525 wiernych, w Gańczarach 404, w Czerepiniu $37^{20}$. Po drugiej wojnie światowej, w okresie ekspatriacji Polaków, wraz z wiernymi wyjechał 5 IV 1946 r. ostatni proboszcz ks. Stanisław Sadowski. Klucze do świątyni zostały oddane greckokatolickiemu komitetowi cerkiew-

17 Zdarzały się napady i kradzieże własności tych rodzin, a nawet zabójstwa miejscowych Żydów. Do tragicznego zdarzenia w Dawidowie doszło m.in. w nocy 21 V 1890 r. We własnym domu zostali wówczas uduszeni Małka Fisch i jej syn Chaim Fisch. Przestępcy zrabowali korale, zastawę stołową i nieznaną kwotę gotówki. Podejrzenie sędziego śledczego przybyłego ze Lwowa na miejsce tragedii padło na drugiego syna, Icka Fischa, który mieszkał w innej chacie i był w konflikcie z matką. Przy nim została znaleziona książeczka kasy oszczędnościowej na nazwisko matki z wkładem 160 guldenów. Został on aresztowany. Także podejrzany o zabójstwo został aresztowany przez żandarmów z Zimnej Wody Mikołaj Szargut pochodzący z Mszany, który w 1887 r. był już skazany za morderstwo na dwa lata więzienia. Do aresztu trafiła także jego żona Maria Szargut, pochodząca z Dawidowa. Kronika, Gazeta Lwowska, 24 V 1890, nr 118; tamże, 29 V 1890, nr 121.

18 Dawidów, Słownik geograficzny Królestwa Polskiego i innych krajów słowiańskich, t. I, Warszawa 1880, s. 915; Catalogus universi Venerabilis Cleri. Saecularis et Regularis Archidioecesis Leopolitanae, Leopoli 1879, s. 31.

19 J. Bigo, Najnowszy skorowidz wszystkich miejscowości z przysiótkami w Królestwie Galicyi, Wielkiem Księstwie Krakowskiem i Księstwie Bukowińskiem z uwzględnieniem wszystkich dotąd zaszłych zmian terytoryalnych kraju, Lwów 1904, s. 34, 46.

20 Schematismus Universi Saecularis er Regularis Cleri Archi Diaeceseos Metrol. Rit. Lat., Leopoli 1936, s. 167. 
nemu. Po wyjeździe proboszcza i parafian kościół został zdewastowany. W latach dziewięćdziesiątych XX w. budynek przejęła Cerkiew greckokatolicka. Świątynia została wyremontowana i przystosowana do wymogów obrządku wschodniego. $\mathrm{Na}$ zewnętrznej ścianie została zachowana niewielka tabliczka z czasów II Rzeczypospolitej z napisem w języku polskim „Znak wysokości”. Na tabliczce znajduje się orzeł w koronie. Obok orła litery P i N. Współcześnie teren wokół cerkwi św. Bogurodzicy jest zadbany, wyłożony kostką brukową i ogrodzony. Wzdłuż ogrodzenia widoczne są próchniejące duże pnie po wyciętych starych drzewach. Przy wejściu głównym na teren cerkiewny obok dzwonnicy stoją dwa duże krzyże, drewniany i kamienny.

\section{Cmentarz obok współczesnej cerkwi (dawnego kościoła parafialnego św. Stanisława)}

W Dawidowie obok cerkwi znajduje się cmentarz. Współcześnie zajmuje dość duży teren. Zaczyna się kilka metrów od głównego wejścia do cerkwi i rozciąga się na wzgórzu, na długości kilkuset metrów. W dolnej części cmentarza, przylegającej do ulicy, jest szeroka brama cmentarna. Od niej kilkadziesiąt metrów w głąb cmentarza prowadzi aleja z kostki brukowej. W głębi cmentarza aleja jest trawiasta. Najstarsza część użytkowanego współcześnie cmentarza znajduje się w pobliżu cerkwi i rozciąga się na zboczu pagórka. Jest to teren, na którym w przeszłości istniał przykościelny cmentarz - miejsce spoczynku mieszkańców Dawidowa w czasach I Rzeczypospolitej i w pierwszych dziesięcioleciach zaboru austriackiego. Zgodnie z inwentarzem z 1789 r. w Dawidowie mieszkały rodziny o nazwiskach: Baran, Berbecki, Blicharski, Brzecko, Broszko, Brzosko, Cap, Czech, Duda, Dyzio, Fedyszyn, Gardziel, Golewicz, Grab, Hołoda, Hreczuch, Huk, Hyrowski, Jaremko, Jarosz, Kobylecki, Komar, Korniak, Kotiuszka, Kuchta, Kuryło, Kuśnierz, Łopatka, Majkowski, Malinowski, Mazur, Mazurkiewicz, Michalski, Młotek, Najda, Ochman, Onyszko, Palica, Porycki, Romanow, Rozmyślewicz, Sawicki, Skwarek, Steczko, Szałagan, Szczyrko, Szeremeta, Szmagacz, Śliwka, Tymczyszyn, Upirko, Woronecki, Wrzyszcz, Zdęba, Zielonka ${ }^{21}$. Prawdopodobnie część zmarlych członków wymienionych rodzin na przełomie XVIII i XIX w. spoczęła na przykościelnym cmentarzu. Pozostali zostali pochowani na nowym cmentarzu poza wsią.

21 Mieszkańcy Dawidowa w 1789 r., dawidow-lwow.blogspot.com/2016/07 [dostęp: 12 VII 2019]. 
Na współczesnym cmentarzu obok cerkwi, wśród grobów, które sytuowano po drugiej wojnie światowej, od drugiej połowy lat czterdziestych $\mathrm{XX}$ w. po czasy obecne, z inskrypcją na krzyżach metalowych i płytach nagrobnych w języku ukraińskim, zachowały się nieliczne upamiętnienia dawnych pochówków w języku polskim. W środku najstarszej części cmentarza stoi charakterystyczny wysoki krzyż o szerokich ramionach, wykonany z kamienia. Na krzyżu inskrypcja jest nieczytelna. Można jedynie przeczytać słowo „proszą”. W pobliżu znajduje się jeszcze jeden kamienny krzyż. Niestety i na nim inskrypcja jest nieczytelna. Takie kamienne krzyże nie występują na innych cmentarzach położonych na obrzeżach Lwowa. Pochodzą z XVIII lub z pierwszych dziesięcioleci XIX w. Są przykładem sztuki sepulkralnej na wiejskich cmentarzach dawnych polskich ziem południowo-wschodnich. Poza tymi dwoma krzyżami na najstarszej części cmentarza, w pobliżu cerkwi, znajduje się niski pomnik zwieńczony krzyżem, wykonany z szarego piaskowca. Na pomniku zachowała się częściowo czytelna inskrypcja: „Spoczywa tutaj Antoni [...]arowicz (23 V 1804-[...])”. Pomnik został ustawiony w XIX w. Obok płotu cmentarnego leży na ziemi fragment pomnika w kształcie charakterystycznej kapliczki z szarego piaskowca z widniejącym napisem: „Spoczywa tutaj [...] Szurgut”. Pozostała część inskrypcji jest zniszczona. Pomniki w kształcie specyficznych kapliczek z szarego piaskowca były bardzo często stawiane na cmentarzach wiejskich pod Lwowem w drugiej połowie XIX w., po 1939 r. Prawdopodobnie kolejne miejsce spoczynku Polaków, dawnych mieszkańców Dawidowa, upamiętniał stary pomnik wykonany z szarego piaskowca, którego fragment zachowal się kilkanaście metrów od świątyni. Pierwotnie na cokole pomnika stał krzyż. Został zniszczony. Na cokole uległa zniszczeniu także inskrypcja.

Na czynnym cmentarzu w Dawidowie zachował się betonowy nagrobek z utrąconym krzyżem ze schyłkowego okresu bytności Polaków na swojej ziemi, po wyparciu niemieckich wojsk okupacyjnych przez Armię Czerwoną. Pomnik upamiętnia Stanisława Śliwę (1863-1945). W lipcu 2019 r. na grobie ziemnym stał krzyż metalowy z owalną tabliczką. Upamiętniał pochowanego tutaj Albina Miazgę (15 XI 1914-14 XI 1945). Miazga zginął tragicznie. Nieznane są okoliczności jego śmierci. Na początku września 2019 r. na krzyżu metalowym na grobie Albina Miazgi już nie było owalnej tabliczki. Na czynnym cmentarzu w Dawidowie nie ma więcej miejsc spoczynku Polaków upamiętnionych w ojczystym języku.

Na cmentarzu obok dawnego kościoła św. Stanisława są upamiętnienia zmarłych nowych mieszkańców Dawidowa, przybyłych po ekspatriacji Polaków. Według relacji Ukraińców, obecnych mieszkańców wsi, którzy nie chcieli podać swoich nazwisk, 
po wyjeździe Polaków w 1946 r., na miejscu zostało jedynie kilkanaście rodzin ukraińskich. Pozostali też Polacy z rodzin polsko-ukraińskich. Puste domy mieszkalne i budynki gospodarcze pozostawione przez Polaków zostały splądrowane, niektóre zdewastowane. Wieś zasiedlono rodzinami ukraińskimi wysiedlonymi z Polski i przybyłymi z innych rejonów radzieckiej Ukrainy.

Najstarsze krzyże metalowe i betonowe nagrobki z inskrypcją w języku ukraińskim w dolnej części cmentarza, w pobliżu cerkwi, pochodzą z drugiej połowy lat czterdziestych XX w. Na tym obszarze istniał historyczny cmentarz obok kościoła, na którym spoczęli mieszkańcy parafii rzymskokatolickiej, zmarli jeszcze w pierwszej połowie XIX w. Po drugiej wojnie światowej został on zapełniony nowymi grobami, które sytuowano tu do końca lat sześćdziesiątych XX w. W 1969 r. cmentarz został poszerzony. Wówczas poświęcono dalszy teren pod nowe groby. Stoi tam duży drewniany krzyż, który upamiętnia to wydarzenie. Kolejne poszerzenie cmentarza nastąpiło w 1986 r. Upamiętnia to duży drewniany krzyż z tabliczką. Napis na tabliczce w języku ukraińskim brzmi: „Ten cmentarz poświęcony w 1986 r. ku pamięci ludzi”. Najnowszy teren cmentarza, na płaskim grzbiecie wzgórza, został poświęcony w 2000 r. Wydarzenie to upamiętnia duży betonowy krzyż. Znajdują się tutaj groby zmarłych w ostatnim czasie mieszkańców Dawidowa i bliskiej okolicy.

Na czynnym cmentarzu w Dawidowie dominują nagrobki wykonane z lastrico w latach siedemdziesiątych i osiemdziesiątych XX w. oraz współczesne pomniki. Na wielu nowych płytach nagrobnych zgodnie z obowiązującym na Ukrainie trendem, zostały umieszczone wizerunki zmarlych. W ostatnich latach zostało wybudowanych na cmentarzu kilka grobowców. Na wprost wejścia do cerkwi, w odległości dziesięciu metrów jest duży nowy pomnik, postawiony w miejscu spoczynku ks. Stepana Stachurskiego (6 I 1913-17 IV 1985), proboszcza cerkwi w Dawidowie w latach 1964-1985. Spoczywa z nim prawdopodobnie córka Larysa Stachurska (28 V 1952-21 II 1955). W pobliżu dzwonnicy znajduje się grób, w którym spoczęła żona kolejnego proboszcza cerkwi w Dawidowie, Katerina Iwaniwna Junko (9 X 1938-20 VII 2008). Na nowej płycie nagrobnej we wrześniu 2019 r. było wyryte nazwisko i jedynie data urodzin proboszcza ks. Oleksija Junki (6 IV 1936-?). Na cmentarzu obok cerkwi w Dawidowie spoczywa bardzo duża liczba osób o polskobrzmiących nazwiskach zapisanych w języku ukraińskim. Nie jest to jednak dowód na to, że byli to Polacy. Większość z nich to Ukraińcy i ich potomkowie, przesiedleni po drugiej wojnie światowej z terenu Polski. Spoczywają tutaj m.in. członkowie rodzin Bodnarów, Czerkasów, Kasztelanów, Kolasów, Kossaków, Kowalików, Kowalów, Kydryńskich, Kretów, Polańskich, Seniuków, Smolniczaków, Zawadzkich. 


\section{Cmentarz „polski”}

Za Dawidowem, przy skrzyżowaniu dróg do Bóbrki i Gańczar, znajduje się teren historycznego cmentarza. Cmentarz powstał na początku okresu, kiedy teren ten znajdował się pod zaborem austriackim, zgodnie z obowiązującym wówczas w Galicji austriackim prawem sanitarnym. Zaborca po zagarnięciu ziem polskich wprowadził szereg przepisów sanitarnych, w tym zakazujących grzebania zmarłych na terenie miejscowości i obok kościołów. Każda wspólnota parafialna i gmina administracyjna miała obowiązek wyznaczenia nowego cmentarza, poza obszarem zabudowań miejscowości ${ }^{22}$. Cmentarz został erygowany na niewielkim wzgórzu. Swoją funkcję pełnił do czasu ekspatriacji Polaków po drugiej wojnie światowej. Później, pozostawiony bez opieki, został zdewastowany i zarósł roślinnością. Z krajobrazu cmentarza w okresie radzieckiej Ukrainy znikły krzyże drewniane i metalowe oraz częściowo kamienne pomniki. Niektóre pomniki zostały przewrócone. Z cokołów znikły kamienne krzyże czy figury Matki Bożej. Nowi mieszkańcy Dawidowa po drugiej wojnie światowej zaczęli grzebać zmarłych zgodnie z tradycją obrządków wschodnich obok cerkwi, wówczas zamkniętego kościoła św. Stanisława, gdzie istniały pozostałości opisanego wyżej dawnego cmentarza, pamiętającego czasy I Rzeczypospolitej. Ukraińcy przybyli po drugiej wojnie światowej do Dawidowa nie sytuowali nowych mogił na cmentarzu przy skrzyżowaniu dróg do Bóbrki i Gańczar. Do dziś na tym cmentarzu nie ma miejsc spoczynku powojennych mieszkańców Dawidowa. Współcześnie jest to cmentarz o charakterze historycznym. Miejscowa ludność ukraińska nadal mówi o nim „cmentarz polski”.

W czasie zaboru austriackiego, w okresie II Rzeczypospolitej, po lata drugiej wojny światowej do grobów na cmentarzu za wsią zostali złożeni mieszkańcy parafii. Zgodnie z Regestrum Mortuorum, prowadzonym przez parafię rzymskokatolicką w Dawidowie na przykład w 1850 r. zmarli mieszkający w Dawidowie członkowie rodzin: Baranów, Blicharskich, Buzewiczów, Czerneckich, Dudów, Grabów, Huków, Jaroszów, Korzeniowskich, Karabanów, Kijaczków, Kobyleckich, Kotiuszków, Lenkowskich, Mazurów, Moczarskich, Mozołów, Najdów, Pękalskich, Szeremetów, Szymonowiczów, Woronieckich, Wrzyszczów, Wyspiańskich. W Gańczarach z ro-

22 Na temat prawa cmentarnego w Galicji zob.: R. Tomczyk, Prawo cmentarne w Galicji pod rzadami Austrii, [w:] Nekropolie na Wschodzie, red. B. Patlewicz, R. Tomczyk, Szczecin 2017, s. 7-24. 
dziny Muchów ${ }^{23}$. Z kolei w 1881 r. zmarli mieszkańcy parafii z rodzin: Blicharskich, Broszków, Buzdryganów, Chirowskich, Czerwińskich, Dudów, Filipowiczów, Gardzielów, Grabów, Gródeckich, Hansów, Hołyńskich, Hukowskich, Huków, Jaroszów, Kasprzyków, Korzeniowskich, Kotiuszków, Krzyczkowskich, Kurkowskich, Majkowskich, Mazurów, Muchów, Podolskich, Porzyckich, Sawickich, Szeremetów, Szołdrów, Szugutów, Szpilów, Zielonków ${ }^{24}$. Prawdopodobnie wszyscy (lub większość) zostali pochowani na cmentarzu za wsią. Na przykładzie zestawienia zgonów z 1850 i 1881 r. dostrzegamy powtarzalność części nazwisk. W Dawidowie i Gańczarach żyły w kolejnych dziesięcioleciach po czas ekspatriacji w 1946 r. następne pokolenia z wymienionych rodzin.

$\mathrm{Na}$ historycznym cmentarzu parafialnym zachowało się niewiele upamiętnień miejsc spoczynku dawnych mieszkańców Dawidowa, Gańczar oraz Czerepinia $\mathrm{w}$ formie pomnika lub krzyża. Godne podkreślenia jest to, że cmentarz ten w ostatnich kilkunastu latach jest pod opieką mieszkających w Polsce potomków rodzin, które na nim spoczęły. Potomkowie Polaków z Dawidowa, głównie z Dolnego Śląska uporządkowali cmentarz, ustawili zwalone na ziemię pomniki i odnowili napisy. W 2010 r. w cerkwi (dawnym kościele św. Stanisława) odbyła się msza ekumeniczna, następnie przemarsz na cmentarz, gdzie został uroczyście odsłonięty pomnik poświęcony pochowanym na tym cmentarzu. W uroczystości wzięli udział członkowie rodzin z Polski na czele z politykiem Polskiego Stronnictwa Ludowego dr. Tadeuszem Samborskim, byłym posłem na Sejm RP, który urodził się w Gańczarach, oraz ówczesnym konsulem Rzeczypospolitej Polskiej we Lwowie Grzegorzem Opalińskim i mieszkańcami Dawidowa. Nie zabrakło polskich mediów. Na cmentarzu został wówczas odsłonięty pamiątkowy pomnik z wysokim krzyżem i pionowymi płytami po jego bokach oraz niską tablicą informacyjną. Teren wokół pomnika został wyłożony płytami, obok pomnika zaś, na niewielkim cokole umieszczono figurę klęczącego anioła. Na pamiątkowej tablicy został umieszczony napis w językach polskim i ukraińskim: „Ku pamięci mieszkańców Dawidowa i Gańczar pochowanych

23 Archiwum Główne Akt Dawnych w Warszawie (dalej AGAD), Księgi metrykalne parafii wyznania rzymskokatolickiego z terenu archidiecezji lwowskiej. Parafia Dawidów dekanat Szczerzec. Ekstrakty z księgi metrykalnej urodzin, ślubów i zgonów dla wsi Dawidów, Gańczary, Czerepin, sygn. 273.

24 Tamże, Księgi metrykalne parafii wyznania rzymskokatolickiego z terenu archidiecezji lwowskiej. Parafia Dawidów dekanat Szczerzec. Kopie z ksiąg metrykalnych urodzin, ślubów i zgonów dla wsi Dawidów i pozostałych wsi, sygn. 1749. 
na tym cmentarzu do 1946 roku. Potomni z Polski 2010”25. Na dwóch pionowych płytach, stojących po obu stronach krzyża zostały umieszczone nazwiska rodzin. Napis głosi: „Tu spoczywają świętej pamięci zmarli z rodzin: Baczmańskich, Baranów, Baranowiczów, Blicharskich, Buguszów (Bogoszów? - RT), Borskich, Broszków, Bużdyganów, Chirowskich, Chrzanowskich, Czerwińskich, Dacko, Dudów, Durbajłów, Dzundziów, Fedyszynów, Godyniów, Grabów, Grodeckich, Grząstków, Gulewiczów, Guwerów, Hawryluków, Hreczuków, Hryciów, Huków, Huzarów, Jaremków, Jaroszów, Kacperków, Karczewskich, Karkowskich, Klimasiewiczów, Kobyleckich, Korzeniowskich, Kotiuszków, Lisów, Liszczyszynów, Łokietków, Łupickich, Maciejaków, Makaryków, Małeckich, Marczaków, Mastalerzy, Mazurów, Młotków, Młynaryczów, Morów, Muchów, Offmanów, Olejników, Paliców, Patyków, Pernalów, Podbuckich, Repczyńskich, Rusinów, Rzepskich, Samborskich, Sawickich, Soroków, Stopińskich, Szeremetów, Szurgutów, Śliwaków, Śliwków, Śmietańskich, Tatałów, Urbańskich, Wojciechowskich, Wrzyszczów, Zdębów, Zdunowskich, Zielińskich, Zielonków, Żukowskich ... i inni”. Jest to swoista Liber Mortuorum stworzona po latach przez potomków dawnych mieszkańców. Po lewej stronie tego dużego pomnika znajduje się również nowy duży nagrobek upamiętniający pochowanych na cmentarzu członków rodziny Guwerów: Wojciecha (1833-1867), Honoraty (1837-1894), Jana (1857-1931), Heleny (1870-1940), Piotra (1888-1920), Stanisława (1891-1912), Heleny (1897-1920) Antoniego (1907-1925), Zbigniewa (1920-1921). Należy dodać, że w bliskiej odległości od skrzyżowania z drogą na Gańczary zachował się stary pomnik z szarego piaskowca, który pierwotnie zwieńczał krzyż żeliwny. Pomnik stoi na grobie rodzinnym Guwerów, który jest otoczony betonową ramą. $\mathrm{Na}$ pomniku zachował się niepełny zapis nazwiska rodziny „[...] uwerów”. Na tym pomniku znajduje się tylko pięć imion z tych, które wymienione są na nowym pomniku: Honorata (1837-1894), Stanisław (1891-1912), Piotr (1 VIII 1888-13 III 1920),

25 Była to ważna inicjatywa ratowania polskiego dziedzictwa na starym rzymskokatolickim cmentarzu na ziemi lwowskiej, podjęta przez potomków dawnych mieszkańców. Takich inicjatyw w okolicy Lwowa było więcej. Należy wskazać na ratowanie polskich pomników na cmentarzu w Czyszkach za Winnikami przez Marka Bartosiewicza z Dąbrowy Górniczej. Było to tym bardziej ważne, że rada gminy w Czyszkach przyjęła uchwałę o likwidacji do 2011 r. polskich śladów na tym cmentarzu. Dzięki staraniom Marka Bartosiewicza rada gminy w Czyszkach przyjęła uchwałę o przekazaniu pod lapidarium 600 metrów kwadratowych na miejscowym cmentarzu. W lipcu 2010 r. została utworzona „Polska Kwatera Pamięci” (lapidarium), na którym znalazło się 100 pomników z mogił Polaków, mieszkańców wsi, którzy zmarli do 1945 r. W centralnym miejscu „Polskiej Kwatery Pamięci” została umieszczona pamiątkowa tablica w języku polskim i ukraińskim. Kwatera została ogrodzona niewysokim betonowym murem. 
Zbigniew (1920-1921) i Helena (1897-192[...]). Tuż obok nowego pomnika rodziny Guwerów znajduje się jeszcze jeden współcześnie postawiony kamienny krzyż z wizerunkiem Matki Bożej, który upamiętnia zmarłego Jana Podbuckiego (1882-1930). W końcowej części cmentarza znajduje się zrekonstruowany pomnik z zachowaną oryginalną środkową częścią wykonaną z szarego piaskowca. Na pomniku została umieszczona nowa tablica, która upamiętnia zmarłych i pochowanych na cmentarzu członków rodziny Rusinów: Grzegorza (1798-1836), Anastazji, Rozalii (*1814), Marcina (*1816), Marii (1842-1876), Michała (1848-1928), Szymona (*1850), Justyny ( $\left.{ }^{*} 1850\right)$, Łukasza (1884-1922), Marcina (1893-1943).

W pobliżu nowego kamiennego krzyża, który upamiętnia zmarłego Jana Podbuckiego, zachował się fragment starego cokołu pomnika z szarego piaskowca, na którym został zamocowany nowy krzyż. Został tutaj pochowany Mikołaj Szurgut (1827-6 I 1894). Jest to, obok grobu wcześniej wymienionej Honoraty Guwer, najstarsze zachowane upamiętnienie pochowanej osoby. Z końca XIX w. zachowało się miejsce spoczynku zmarłej w wieku dwudziestu dziewięciu lat Józefy Dudy $(+1900)$. Na jej grobie stoi kamienny cokół z fragmentem ułamanego krzyża metalowego. Wielu grobów, które zostały usypane w XIX w., nie ma. Nieliczne informacje na temat mieszkańców Dawidowa zmarłych w drugiej połowie XIX w. znajdują się w prasie lwowskiej. 25 XII 1865 r. doszło do pożaru słomy w jednym z miejscowych domów. Powstały dym zadusił dwoje małych dzieci, które były zamknięte w budynku. Prasa nie podała nazwisk zmarłych dzieci ${ }^{26}$. Głośną sprawą, opisywaną w gazetach, było morderstwo dokonane w nocy z 13 na 14 III 1867 r. na osobie proboszcza w Dawidowie, ks. Łukasza Flisowskiego. Ciało księdza znaleziono rankiem, został zaatakowany w czasie snu. Miał cięte rany na szyi i dwie kule w piersi, które przeszyły serce i płuca. Proboszcz stał się ofiarą napadu rabunkowego, podczas którego skradziono kilka tysięcy guldenów w złocie i srebrze oraz książeczki kasy oszczędnościowej. Dwóch napastników wkrótce ujęto i odstawiono do aresztu sądu powiatowego w Bóbrce. Byli to: dawny organista w Dawidowie oraz syn woźnego z okolicy ${ }^{27}$. Śmiercią naturalną

26 Kronika, Gazeta Lwowska, 8 I 1866, nr 5. Wcześniej prasa lwowska odnotowała dwa pożary w Dawidowie, w których na szczęście nie było ofiar śmiertelnych. 26 III 1864 r. w wyniku nieostrożności został zaprószony ogień w gospodarstwie Jana B. w Dawidowie. W pożarze spłonął drewniany dom. 1 IX 1865 r. spalił się w Dawidowie drewniany barak stojący na nasypie kolejowym. Według doniesień prasowych miało to być podpalenie. Kronika, tamże, 4 IV 1864, nr 77; tamże, 5 IX 1865, nr 203.

27 Kronika, tamże, 16 III 1967, nr 64; Kronika, Gazeta Narodowa, 16 III 1867, nr 63; Kronika, tamże, 17 III 1867, nr 64. 
w wieku 49 lat zmarł kolejny proboszcz ks. Albinus Hauptmann (†17 VIII 1876). Ks. Hauptmann pracował w Dawidowie jako proboszcz dziewięć lat. Był uzdolniony muzycznie. Przywiązywał wagę do oprawy wokalno-muzycznej nabożeństw i innych uroczystości kościelnych. Pogrzeb duchownego odbył się 19 VIII 1876 r. z udziałem ks. kanonika Józefa Siekanowicza, proboszcza w Zimnej Wodzie, dziekana gródeckiego i szczerzyckiego. Nie jest wykluczone, że ks. Albinus Hauptmann spoczął na dawnym cmentarzu przykościelnym ${ }^{28}$. W nocy z 11 na 12 V 1897 r. w Dawidowie miejscowy chłop Jan Duda zamordował swojego brata, jego żonę zaś pobił. Do zbrodni doszło po kłótni, w której brat zagroził Janowi Dudzie, że doniesie żandarmom o sprawcy niewykrytego morderstwa miejscowej karczmarki sprzed kilku lat. Sprawcą morderstwa miał być Jan Duda. Po zabójstwie brata został aresztowany ${ }^{29}$.

Na historycznym cmentarzu w Dawidowie więcej pomników zachowało się na grobach zmarlych w pierwszej dekadzie XX w., do wybuchu pierwszej wojny światowej. Wysoki pomnik wykonany z szarego piaskowca, zwieńczony krzyżem, upamiętnia zmarłego w wieku 19 lat Jana Stankiewicza (†1907). Niska kapliczka z małym krzyżem wykonana także z szarego piaskowca stoi w miejscu spoczynku zmarłej w wieku dwóch lat Anisi Zbomińskiej (†1909). Prawdopodobnie w okresie międzywojennym został postawiony betonowy nagrobek z krzyżem na grobie Jana Kobyleckiego (†1909). Pomnik w kształcie charakterystycznej kapliczki z utrąconym krzyżem, również z szarego piaskowca, zachował się obok dużego drzewa. W przyziemiu, w niszy kaplicznej znajduje się nadal częściowo zniszczona figura Matki Bożej. Spoczywa tutaj Maria Macibiak (1850-1910). Ciekawym przykładem sztuki sepulkralnej z pierwszych dziesięcioleci XX w. jest duży pomnik z charakterystycznym krzyżem z szarego piaskowca. Pomnik upamiętnia pochówek zmarłej w wieku 75 lat Rozalii Huk (†21 IX 1910). Betonowy nagrobek z krzyżem stoi na miejscu spoczynku zmarłej w wieku 48 lat Anny Śmietańskiej (†1911). Kolejny betonowy pomnik z odłamanym krzyżem upamiętnia zmarłego w wieku 44 lat Jana Skrota (†1911). Duży betonowy nagrobek z krzyżem z zachowanym na nim Jezusem Chrystusem stoi na miejscu spoczynku Stanisława Chrzanowskiego (1850-20 III 1912). W dobrym stanie zachował się do czasów współczesnych, na skraju cmentarza, przy drodze Lwów-Bóbrka, pomnik w formie charakterystycznej kapliczki z krzyżem. We wnęce kaplicznej jest rzeźba duchownego, który trzyma krzyż. Pomnik upamięt-

28 dawidow-lwow.blogspot.com/search/label/ks.\%20Albinus\%20Hauptmann [dostęp: 10 VIII 2019].

29 Kronika, Kurier Lwowski, 14 V 1897, nr 133; Kronika, Gazeta Narodowa, 14 V 1897, nr 133; Kronika, Dziennik Narodowy, 14 V 1897, nr 133. 
nia miejsce spoczynku zmarłego w wieku 68 lat Jana Szeremety (†22 VIII 1912). Nieopodal zachował się pomnik w formie charakterystycznej „skałki” z niewielkim krzyżem. Obok krzyża jest figura Matki Bożej z odłamaną głową. Upamiętnia zmarłego w „pierwszej wiośnie życia” Zdzisia Cichackiego (†1912).

$\mathrm{Na}$ historycznym cmentarzu w Dawidowie zachowały się dwa upamiętnienia $\mathrm{z}$ inskrypcją $\mathrm{w}$ języku polskim zmarłych w czasie pierwszej wojny światowej. Jedno $\mathrm{z}$ nich to fragment tablicy z szarego piaskowca, która wspomina Karola Władysława Bartaka (28 II [...] - 25 VI 1915). Niski cokół z piaskowca pozbawiony krzyża (prawdopodobnie był to krzyż żeliwny) stoi na miejscu spoczynku zmarłego w wieku 27 lat Józefa Szpera $(† 1915)$. W środkowej części cmentarza stoi kamienny pomnik z przymocowanym współcześnie fragmentem krzyża. Na frontowej ścianie pomnika znajduje się częściowo zniszczona inskrypcja : „[...] [...] ewicz $(+1915)$ ”. W tym grobie została także pochowana w czasach II Rzeczypospolitej Teresa Mazur (†1927). Nieopodal stoi duży pomnik kamienny pozbawiony krzyża, na którym znajdują się imiona zmarlych z rodziny Zielonków, ale obok nich nie zostały umieszczone daty. Zostali tutaj pochowani członkowie rodziny: Tomasz, Agnieszka, Piotr, Franciszek. Przy imieniu Franciszek został wyryty napis: „zginął na wojnie”. Poniżej umieszczono napis: „Nagrobek poświęcony zm. członkom rodziny Zielonków 1935”. Na cmentarzu zachował się pomnik z utrąconym krzyżem i inskrypcją w języku ukraińskim. Stoi na grobie, w którym spoczywa Tomasz Urbański (1840-1 XI 1914). Po latach w tym grobie została pochowana Katarzyna Urbańska (2 III 1872-1 VIII 1937).

W Dawidowie doszło do tragicznych zdarzeń podczas walk z Ukraińcami w latach 1918-1919. Do jednego z nich doszło 27 XI 1918 r., kiedy to do wsi wszedł oddział wojska ukraińskiego. Wówczas Ukraińcy spalili całkowicie 31 zagród oraz wiele pojedynczych domów i budynków gospodarczych. Został podpalony także miejscowy dwór. Żołnierze ukraińscy dokonali grabieży i zastrzelili sześciu mieszkańców wsi. Jak donosił „Kurier Lwowski”: „szczególnie pastwili się nad dwoma chłopami, których pomawiali o należenie do Legionów. Obu skłuli bagnetami, a potem zastrzelili”30. Prasa podała również, że około $20 \mathrm{~V} 1919$ r. Ukraińcy rozstrzelali w Dawidowie dwóch miejscowych chłopów bez sądu. Nie pozwolili też bliskim na zabranie ich ciał z miejsca kaźni ${ }^{31}$. W Dawidowie został zamordowany przez patrol ukraiński mieszkaniec

\footnotetext{
30 Ogniem i bagnetem $w$ powiecie lwowskim, Kurier Lwowski, 1 XII 1918, nr 525.

31 Ukraińcy zapowiadają mordowanie Polaków, Goniec Częstochowski, 23 V 1919, nr 108, dawidow-lwow.blogspot.com/2016/03 [dostęp: 25 VIII 2019].
} 
wsi Józef Lambucki, który miał przy sobie pokwitowanie za przywiezioną do Lwowa żywność. Spoczął na cmentarzu parafialnym ${ }^{32}$. Groby pomordowanych nie zachowały się do naszych czasów na miejscowym cmentarzu parafialnym. Zgodnie z informacją upowszechnioną drukiem w połowie lat dwudziestych XX w. na cmentarzu w Dawidowie były mogiły 13 polskich żołnierzy, poległych w latach 1918-1919 w walkach z Ukraińcami ${ }^{33}$. Na cmentarzu parafialnym zostali pochowani w zbiorowej mogile zamordowani 29 XII 1918 r. w Dawidowie polscy żołnierze z 5. kompanii 39. Pułku Piechoty, broniący stanowisk w Persenkówce. 28 XII 1918 r. zostali wzięci do niewoli i odstawieni do Dawidowa. Na skraju lasu Ukraińcy odarli ich z ubrań, następnie zamordowali. Wśród ofiar byli: por. Lech Gluziński, absolwent Wydziału Medycznego Uniwersytetu Lwowskiego (24 lata); szer. Julian Mładejowski (pochodził z Lewandówki, miał 17 lat); szer. Jan Moch (pochodził z Lewandówki); szer. Franciszek Walerian Manowarda de Jana (uczeń piątej klasy gimnazjum realnego ze Lwowa, 15 lat); szer. Jerzy Henryk Leliwa Adamowicz ( 30 III 1901, uczeń szóstej klasy XI gimnazjum we Lwowie); szer. Adam Cap (uczeń czwartej klasy szkoły realnej we Lwowie, 14 lat); szer. Jan Kłosowski ( ${ }^{*} 1884$, handlowiec ze Lwowa); st. szer. Adam Nestarowski (*20 IV 1901, uczeń szóstej klasy II szkoły realnej we Lwowie); szer. Franciszek Puczan (pochodził z Lewandówki, 19 lat). Wówczas też miał zostać zamordowany szer. Feglich. Należy jednak dodać, że na tablicy upamiętniającej pomordowanych na skraju lasu w Dawidowie, umieszczonej w okresie międzywojennym na pomniku w Persenkówce nie był wymieniony szer. Feglich. Obok wyżej przedstawionych nazwisk był napis ,jeden nieznany”. Zamordowanych 29 XII 1918 r. polskich żołnierzy w następnym roku ekshumowano i większość z nich została pochowana 23 VI $1919 \mathrm{r}$. na Cmentarzu Obrońców Lwowa. „Gazeta Lwowska”, informując o pogrzebie, podała, że na Cmentarzu Obrońców Lwowa zostali pochowani: por. Lech Gluziński, szer. Jerzy Henryk Leliwa Adamowicz, st. szer. Adam Nestorowski, szer. Franciszek Walerian Manowarda de Jana, szer. Adam Cap i szer. Jan Kłosowski ${ }^{34}$.

W okresie międzywojennym na historycznym cmentarzu w Dawidowie został ustawiony pomnik upamiętniający poległych polskich żołnierzy. Na podstawie po-

32 W obronie Lwowa i Kresów Wschodnich. Polegli od 1-go listopada 1918 do 30 czerwca1919 r., Lwów 1926, s. 165.

33 J. Białynia-Chołodecki, Z dziejów oblężenia i odsieczy Lwowa w latach 1918-1920, [w: ] Kalendarz powszechny „Haliczanin” na rok Pański 1925, Lwów 1925, s. 91; A. Nechay, Zwycięskie Termopyle, [w:] W obronie Lwowa i Kresów Wschodnich, s. 48.

34 Tamże, s. 73-74, 82, 90, 104, 116, 122, 124, 133; Kronika, Gazeta Lwowska, 25 VI 1919, nr 144. 
mnika wyryto napis: „Cześć polskim bohaterom 1918-19”. Górna część pomnika, na której była pamiątkowa tablica, została zniszczona po 1939 r. Przez kolejne dziesięciolecia zachował się na cmentarzu tylko niski cokół. Współcześnie na historycznym cmentarzu parafialnym w Dawidowie znajduje się odnowiony pomnik, który upamiętnia poległych w bitwie 22 V 1919 r. trzech żołnierzy III batalionu 16. Pułku Piechoty Ziemi Tarnowskiej. Wśród poległych był dwudziestodwuletni szer. Kazimierz Durasik. Pochodził z Tarnowa. Pierwotnie został pochowany obok leśniczówki $^{35}$. W lewym górnym rogu nowej tablicy zamontowanej na pomniku został umieszczony napis: „Polegli, abyśmy żyli”. Następnie pod orłem w koronie i krzyżem wyryto tekst: „Pamięci polskich żołnierzy 16 Pułku Piechoty Ziemi Tarnowskiej poległych w bohaterskiej bitwie pod Dawidowem 22 V 1919 r. Cześć Ich Pamięci. Rodacy mieszkańcy Dawidowa i Tarnowa”. Pod napisem, w dolnym lewym rogu tablicy znajduje się pułkowa odznaka pamiątkowa ustanowiona przez ministra spraw wojskowych w 1930 r. Wokół pomnika zachowało się sześć kamiennych słupków, na których pierwotnie wisiał metalowy łańcuch.

Najwięcej pomników lub ich fragmentów, na których zachowała się inskrypcja w języku polskim upamiętnia zmarlych w okresie II Rzeczypospolitej. Poza już wyżej wymienionymi zmarłymi w okresie międzywojennym z początków niepodległej Polski zachował się pomnik z czerwonego piaskowca z dorobionym współcześnie krzyżem z lastrico. Stoi na grobie Grzegorza Wyspiańskiego (14 XI 1905-25 VIII 1920). W rogu cmentarza, przy skrzyżowaniu dróg, jest kamienna „skałka” z nowym betonowym krzyżem. Na krzyżu znajduje się owalna tabliczka upamiętniająca spoczywającego tutaj chłopca - Jerzego Brzozowskiego (18 I 1919-27 X 1923). Przy rzędzie posadzonych niedawno tui wzdłuż drogi ze Lwowa do Bóbrki stoi pomnik z szarego piaskowca z doklejonym współcześnie krzyżem betonowym. Spoczywa tutaj zmarła w wieku 70 lat Marcelia Bożdygan (†1925). Kolejny taki pomnik, również $\mathrm{z}$ doklejonym małym krzyżem betonowym stoi na grobie Marcina Daczmańskiego (†1925) i jego matki Apolonii Daczmańskiej (†1928). Niski cokół z małym krzyżem z szarego piaskowca stoi na grobie, w którym spoczywają „najdroższe dzieci” Piotr Tatało (1920-1926) i Jan Tatało (1922-1926). Kolejny pomnik betonowy z zamontowanym współcześnie małym krzyżem znajduje się na miejscu spoczynku zmarłego w wieku 33 lat Józefa Huka (†15 III 1930). W środkowej części cmenta-

35 W obronie Lwowa i Kresów Wschodnich, s. 88; D. Zielonka, Polegli w wojnie polsko-ukraińskiej 1918-1919, dawidow-lwow.blogspot.com/2016/03 [dostęp: 20 VIII 2019]. Na temat bitwy zob.: Relacja mjr Andrzeja Wajsa dotyczaca bitwy pod Dawidowem 22 V 1919, dawidow-lwow.blogspot.com/2017/02 [dostęp: 20 VIII 2019]. 
rza znajduje się wysoki betonowy nagrobek, który upamiętnia pochowanego tutaj, zmarłego w wieku 20 lat Waleriana Korzeniowskiego (†23 IV 1930). W tym grobie spoczywa również zmarła w wieku 19 lat Franciszka Korzeniowska (†11 VII 1934). W grobie, na którym ustawiony jest kamienny pomnik z zachowanym, chociaż popękanym, oryginalnym krzyżem, spoczywa zmarła w wieku 22 lat Maria Korzeniowska (†2 X 1930). Duży pomnik betonowy z nowym krzyżem z lastrico upamiętnia Karola Miazgę (1884 - 5 IV1932). Grób jest otoczony ramą betonową. Obok jedynego zachowanego na cmentarzu starego, szarego, spróchniałego krzyża drewnianego, pozbawionego ramienia i tabliczki z inskrypcją, jest mały pomnik $\mathrm{w}$ formie kapliczki pozbawiony krzyża. Spoczywa tutaj zmarła w wieku 32 lat Rozalia Jaremko (†17 V 1934). Poniżej jej grobu, w dolnej części cmentarza jest pomnik z czerwonego piaskowca. Upamiętnia pochowanego w tym miejscu Juliana Zdunowskiego (+10 IX 1934), zmarłego w wieku 58 lat. Wraz z nim spoczywa Helena Maciejakowa ze Zdunowskich (15 III 1915-10 IX 1939). Inskrypcja na pomniku informuje, że „Tragicznie zmarła w wojnie Polsko-Niemieckiej”. Jest to jedyne zachowane na historycznym cmentarzu upamiętnienie ofiary kampanii wrześniowej w 1939 r. Niski nagrobek z betonu, na którym krzyż został strącony, stoi na grobie Marcina Bogosza (24 IX 1867-25 IX 1934). Bogosz był emerytowanym pracownikiem P.K.P. Później w tym grobie spoczęła Magdalena Bogosz (†5 VIII 1938). Zmarła w wieku 78 lat. W środkowej części cmentarza został ustawiony nowy nagrobek. Upamiętnia Antoniego Korzeniowskiego (5 VI 1891-5 I 1936), starszego posterunkowego Policji Państwowej. Wraz z nim spoczywa żona Katarzyna Korzeniowska (1895-1938). Nowy krzyż kamienny upamiętnia Michała Podbuckiego (1914-1937), który - jak głosi inskrypcja na krzyżu - „zginął śmiercią tragiczną”. Stary niski cokół pomnika z doklejonym krzyżem z lastrico, pozbawiony jednego ramienia, jest ustawiony na miejscu spoczynku zmarłej w wieku 72 lat Klary Prokop (†1937). Pomnik $\mathrm{w}$ formie kapliczki, wykonany z szarego piaskowca, z nowym krzyżem, upamiętnia zmarłą w wieku 67 lat Anastazję Grab (†7 I 1939). Przed wybuchem drugiej wojny światowej zmarła Waleria Gulewicz z Patyków. Na cokole pomnika wykonanego z szarego piaskowca inskrypcja jest częściowo zniszczona (8 IV 1893-15.[...].[...]). Z czasów II Rzeczypospolitej zachował się pomnik kamienny z nowym krzyżem z lastrico, na którym inskrypcja została wykonana w języku ukraińskim. Upamiętnia pochowanych na cmentarzu Wasyla Tymczyszyna (1879-18 VII 1936) i jego żonę Katarzynę Tymczyszyn z Soroków (5 XI 1883-5 VII 1939).

Na historycznym cmentarzu w Dawidowie zachowało się jeszcze 18 pomników lub ich fragmentów, głównie cokołów i potłuczonych, leżących na ziemi kamien- 
nych płyt, na których nie ma współcześnie już czytelnych inskrypcji. Pomniki te zostały wykonane do 1939 r. Po drugiej wojnie światowej - gdy Polacy opuścili Dawidów i Gańczary, i zabrakło opieki rodzin - uległy zniszczeniu. Pomniki zostały wykonane przede wszystkim z szarego piaskowca - materiału, który dominuje na cmentarzach wiejskich pod Lwowem - przez okolicznych majstrów kamieniarskich. Na niektórych pozbawionych inskrypcji pomnikach lub ich fragmentach zachowały się elementy zdobnicze jak figury aniołów lub Jezusa Chrystusa, częściowo też ornamentyka roślinna.

Najbardziej interesujący pomnik wykonany z szarego piaskowca, o nietypowej formie, niespotykany na cmentarzach Lwowa i pod Lwowem, pozbawiony inskrypcji, zachował się w górnej części cmentarza. Na niskim, wąskim cokole została umieszczona postać osoby duchownej, która siedzi w fotelu, dłonie ma oparte na jego poręczach. Duchowny jest ubrany w sutannę. Okrywa go peleryna, której fałdy opadają za fotelem. Na głowie ma piuskę. Prawo noszenia piuski mieli w dawnych czasach poza hierarchami także inni duchowni diecezjalni. Niestety frontowa część posągu na wysokości klatki piersiowej i kolan została zniszczona. Nie jest pewne, który z duchownych, prawdopodobnie miejscowy proboszcz, został upamiętniony tym nietypowym pomnikiem. Poza wcześniej wspomnianym starym krzyżem drewnianym, pozbawionym tabliczki z inskrypcją, na cmentarzu zachowało się sześć krzyży żeliwnych i metalowych, na których niestety także nie przetrwały tabliczki $\mathrm{z}$ inskrypcją.

W prasie lwowskiej z czasów II Rzeczypospolitej znajdują się nieliczne informacje na temat zmarłych mieszkańców Dawidowa. Są to głównie anonsy o tragicznych zdarzeniach, których ofiary mieszkały we wsi i po śmierci spoczęły na miejscowym cmentarzu przy skrzyżowaniu dróg do Bóbrki i Gańczar. Ich groby się nie zachowały. Tytułem przykładu: wieczorem 14 VI 1922 r. Juliusz Malinowski odprowadził na dworzec kolejowy swojego brata, właściciela restauracji w Dawidowie, który jechał do Lwowa. Gdy pociąg przyjechał na dworzec kolejowy w Dawidowie, Juliusz stanął na schodach wagonu i nadal rozmawiał z bratem. Nie zszedł ze schodów wagonu, gdy pociąg ruszył w kierunku Lwowa. Zeskoczył dopiero po kilkudziesięciu metrach, gdy pociąg nabrał prędkości. Niestety zeskoczył tak nieszczęśliwie, że wpadł pod koła wagonu. Koła odcięły mu nogę i rękę oraz zmiażdżyły głowę. Juliusz Malinowski zmarł na miejscu ${ }^{36}$. W Dawidowie zmarł Feliks Zimmer (†22 X 1924), starszy radca rachunkowy izby skarbowej we Lwowie. Jego pogrzeb odbył się $24 \mathrm{X}$

36 Śmierć pod kołami pociagu, Gazeta Poranna, 16 VI 1922, nr 6411. 
1924 r. na cmentarzu miejscowym ${ }^{37}$. Z nieznanych powodów na drzewie w lesie koło Winniczek powiesiła się około 30 VI 1925 r. Teresa Blicharska z Dawidowa. Śledztwo w sprawie jej śmierci prowadził posterunek policji w Winnikach ${ }^{38} .11$ XI $1925 \mathrm{r}$. pod Dawidowem przy strażnicy nr 14 na linii kolejowej Lwów-Stanisławów rzucił się pod pociąg osobowy siedemdziesięciodwuletni Antoni Olejnik z Dawidowa. Pociąg, którego maszynista Wilhelm Fidler nie był w stanie zatrzymać, zmasakrował ciało Olejnika. W czasie śledztwa ustalono, że Olejnik skoczył pod lokomotywę w ostatniej chwili. Powodem rozpaczliwego kroku była nędza. Czyn popełnił po kilku dniach głodowania, kiedy jego rodzina mu nie pomogła ${ }^{39}$. Podczas obchodu lasu należącego do oo. dominikanów (obok Dawidowa) leśniczy natknął się 19 VI 1926 r. na wiszące na drzewie ciało. Powiadomił o tym miejscowy posterunek policji. Ustalono, że był to Michał Gródecki, pięćdziesięcioośmioletni gospodarz z Dawidowa, który powiesił się z braku sił do pracy i niechęci do życia, o czym mówił od dłuższego czasu wedle słów żony ${ }^{40}$. Około 26 IV 1927 r. gospodarz z Dawidowa, liczący osiemdziesiąt lat Jan Kuryło, pozbawił się życia brzytwą. Od dłuższego czasu cierpiał na nieuleczalną chorobę. W przystępie rozstroju nerwowego rozpruł sobie brzuch, następnie poderżnął gardło. Tragiczny krok Kuryły spostrzegli domownicy. Jednak na ratunek było już za późno. Zmarł wkrótce w strasznych męczarniach, z powodu obrażeń i upływu krwi ${ }^{41}$. Duże gospodarstwo rolne posiadał w Dawidowie Piotr Jaremko. Prowadził je z żoną Marią. 5 V 1929 r. doszło do sprzeczki Piotra Jaremki z siedemnastoletnim synem Michałem. Syn chwycił nóż i pchnął ojca w szyję. Wskutek silnego krwotoku ojciec zmarł. Posterunek policji w Dawidowie aresztował Michała Jaremkę i odstawił go do więzienia sądu karnego we Lwowie ${ }^{42}$. Około

\footnotetext{
37 Kronika, Kurier Lwowski, 24 X 1924, nr 244.

38 Cztery samobójstwa w jednym dniu, tamże, 1 VII 1925, nr 151; Kronika, Gazeta Lwowska, 1 VII 1925, nr 147.

39 Staruszek 72-letni rzucit się z nędzy pod pociag, Kurier Lwowski, 13 XI 1925, nr 266.

40 Wisielec $w$ lesie OO. Dominikanów, tamże, 21 VI 1926, nr 141.

41 Wiadomości z kraju, Dziennik Ludowy, 28 IV 1927, nr 96.

42 Syn zabit ojca, Wiek Nowy, 9 V 1929, nr 8364; Pchnięciem noża zamordowat ojca, Dziennik Ludowy, 9 V 1929, nr 104; Ojcobójca, Słowo Polskie, 13 IX 1929, nr 251. Prawdopodobnie wiele lat wcześniej, około 26 VIII 1901 r., wówczas młody gospodarz Piotr Jaremko, spokojnie pijąc piwo w karczmie Uszera Barola za lwowską rogatką Zieloną, został zaatakowany i mocno pokaleczony nożem przez miejscowego apasza Józefa Warzęchę. Jaremko udał się na pogotowie ratunkowe, które mu udzieliło pomocy, następnie swoim wozem konnym wrócił do domu do Dawidowa. Kronika, Słowo Polskie, 27 VIII 1901, nr 397.
} 
18 VII 1930 r. mieszkanka Dawidowa Maria Łuszczyńska zamordowała swoje nieznane z imienia czteromiesięczne dziecko. Później sama próbowała popełnić samobójstwo. W stanie ciężkim została odwieziona do szpitala ${ }^{43}$.W nocy z 4 na 5 VI 1933 r. jechał ze Lwowa do domu w Dawidowie bez biletu, na dachu pociągu osobowego relacji Lwów-Stanisławów, dziewiętnastoletni Stanisław Miazga. Podczas jazdy na dachu wagonu uderzył głową w żelazne przęsło wiaduktu kolejowego znajdującego się w okolicy Pasiek Zubrzyckich, pomiędzy Sichowem a Dawidowem. Po uderzeniu spadł na nasyp kolejowy. Poniósł śmierć na miejscu ${ }^{44}$. Podobny wypadek, w którym zginął mieszkaniec Dawidowa, miał miejsce jesienią 1934 r. 26 października jechal „na gapę” na dachu wagonu z Dawidowa do Lwowa dwudziestosześcioletni Julian Mazur. W trakcie jazdy nie zauważył wiaduktu kolejowego pod Pasiekami Zubrzyckimi. Uderzył głową w metalowe przęsło wiaduktu, w wyniku czego poniósł śmierć na miejscu ${ }^{45}$. Wcześniej, 26 V 1934 r. dwudziestosześcioletni robotnik Wojciech Śmietański zastrzelił w Dawidowie swojego ojca Józefa Śmietańskiego. Ojciec robił synowi wymówki, że jest leniwy i opieszały w pracy. Wojciech Śmietański został aresztowany i stanął przed sądem we Lwowie. W końcu września 1934 r. został

43 Morderstwa dzieci przez rodziców, Dziennik Ludowy, 20 VII 1930, nr 163.

44 Kronika, tamże, 7 VI 1933, nr 128; Śmiertelna jazda na gapę, Wiek Nowy, 7 VI 1933, nr 9593. Wcześniej, około 10 V 1933 r., z nieznanych powodów Jan Demański, mieszkaniec Winniczek, strzelił z karabinu w kierunku pracujących na polu braci Dudów z Dawidowa. Jednego z nich, Antoniego Dudę, zranił w bok. Ranny został odwieziony do szpitala. W tej sprawie trwało śledztwo. Kronika, Dziennik Ludowy, 12 V 1933, nr 108.

45 Kronika miejska, Gazeta Lwowska, 27 X 1934, nr 255. Należy dodać, że we wrześniu 1934 r. głośnym echem w prasie lwowskiej odbiło się zdarzenie, do którego doszło w Dawidowie i zakończyło się śmiercią człowieka. 9 IX 1934 r. odbywało się wesele w domu Franciszka Siatkiewicza w Dawidowie. Kilku miejscowych parobków będących na weselu szukało pretekstu do pobicia gości przybyłych spoza wsi. Wieczorem po uroczystościach weselnych część gości udała się na miejscowy dworzec kolejowy, aby wrócić pociągiem do domu. Byli to m.in.: Rudolf Śliwiak, Ludwik Lukas, Stefania Sieprawska i Józef Sieprawski ze Lwowa, chorąży Wojska Polskiego. Po drodze na dworzec doszło do zatargu pomiędzy Józefem Sieprawskim a trzema miejscowymi parobkami, którzy obrzucali weselników kamieniami. Sieprawski strzelił wówczas kilka razy w górę z pistoletu, chcąc odstraszyć napastników. Na nic to się zdało. Obok toru kolejowego parobkowie dogonili Sieprawskiego i od jednego z napastników otrzymał cios nożem. Ciężko ranny został przewieziony do szpitala wojskowego we Lwowie. Zmarł w szpitalu i 18 IX 1934 r. został pochowany we Lwowie. Policja w Dawidowie prowadziła dochodzenie w sprawie śmiertelnego pobicia chorążego. Początkowo aresztowano trzy osoby: Stefana Kmeta, Józefa Dońca i Stanisława Lakrojca. Następnie został aresztowany dwudziestoletni Antoni Jaremko, który został oskarżony o zabójstwo. Mord na osobie choraż̇ego w Dawidowie, Wiek Nowy, 19 IX 1934, nr 9978; Proces o zabójstwo chorążego, tamże, 1 I 1935, nr 10090. 
skazany na dziesięć lat więzienia ${ }^{46}$. Późnym wieczorem 12 II 1938 r. gospodarz z Dawidowa Kazimierz Palica wyciął drzewo o długości $9 \mathrm{~m}$ w lesie oo. dominikanów. Gdy wyniósł drewno na skraj lasu i chciał je transportować do domu, nagle zmarł. Gdy po kilku godzinach nie wracał do domu, zaniepokojona żona wraz z synem zaczęła go szukać. Znalazła ciało męża na skraju lasu. Kazimierz Palica miał czterdzieści dwa lata ${ }^{47}$. Groby wymienionych tragicznie zmarłych w czasach II Rzeczypospolitej mieszkańców Dawidowa się nie zachowały.

$\mathrm{Na}$ historycznym cmentarzu parafialnym w Dawidowie nie zachowały się, poza wcześniej wspomnianą Heleną Maciejakową ze Zdunowskich (która zginęła tragicznie podczas wojny obronnej we wrześniu 1939 r.), groby pochowanych w okresie drugiej wojny światowej. Nie ma już m.in. grobów Polaków, którzy zginęli z rąk ukraińskich. W lipcu 1943 r. w Dawidowie banda UPA obrabowała i spaliła polskie gospodarstwa oraz zamordowała dziewięciu Polaków ${ }^{48}$. Nie można wykluczyć, że na tym cmentarzu zostali pochowani chroniący ludność polską przed napadami Ukraińców lub podczas akcji „Burza” w 1944 r. polegli nieznani żołnierze z 14. Pułku Ułanów Jazłowieckich Armii Krajowej. Zmarli w okresie drugiej wojny światowej spoczęli w grobach ziemnych z krzyżami drewnianymi. W okresie radzieckiej Ukrainy pozbawione opieki groby ziemne uległy zniszczeniu, a drewniane krzyże zostały $\mathrm{z}$ nich usunięte.

Współcześnie proboszcz greckokatolicki w Dawidowie nawołuje wiernych do poszanowania „polskiego cmentarza” i utrzymywania go w należytym porządku. Teren cmentarza uporządkowany przez potomków dawnych mieszkańców z Polski to prostokąt o wymiarach $30 \times 60 \mathrm{~m}$. Teren ten został obsadzony wokół tujami i świerkami. Przy granicy, w dolnej jego części zostały umieszczone symboliczne dwa niewielkie lwy kamienne. Obecnie na środku uporządkowanej części cmentarza rośnie jedno stare drzewo, pozostałe zostały wycięte, zostały po nich pnie. Cmen-

\footnotetext{
46 Syn zabił ojca, tamże, 2 X 1934, nr 9989.

47 Kronika bieżąca, tamże, 15 II 1938, nr 11026. Należy dodać, że wśród chłopów z Dawidowa istniała długoletnia tradycja wycinania drzew w miejscowym lesie w okresie zimowym i wożenia drewna opałowego do Lwowa. Za pokątny handel drewnem opałowym we Lwowie np. w styczniu 1858 r. dwunastu chłopów z Dawidowa zostało ukaranych karami pieniężnymi (Kronika, Gazeta Lwowska, 23 I 1858, nr 18).

48 S. Siekierka, H. Komański, K. Bulzacki, Ludobójstwo dokonane przez nacjonalistów ukraińskich na Polakach w województwie lwowskim 1939-1947, Wrocław 2006, s. 617, 635; 75. rocznica ludobójstwa. Lipiec 1943 r. Obszerne kalendarium. S. Żurek, Kalendarz Pamięci Ludobójstwa na Kresach - lipiec 1943-1952. wolyn.org/index [dostęp: 15 IX 2019].
} 
tarz zajmował niegdyś większy teren. Rozciągał się wzdłuż drogi do Gańczar. Wśród rosnących tutaj drzew i krzewów znajdują się nieliczne stare małe cokoły i leżące na ziemi fragmenty górnych części pomników, pozbawione inskrypcji. Na terenie nieuporząalkowanym, wśród drzew i krzewów, które rosną przy drodze do Gańczar, potomkowie dawnych mieszkańców postawili dwa symboliczne krzyże betonowe.

\section{Summary}

Dawidów near Lvov has a long history. The village was mentioned in the time of Casimir III the Great (1310-1317). Since the $17^{\text {th }}$ century until the fall of the Second Polish Republic, large estates in Dawidów were property of the Lvov Dominicans. The serfdom-based estate adjoined the farms. Across centuries, until expatriation following WWII, Dawidów was inhabited predominantly by Polish Catholics. They were buried in the church cemetery (now a Greek Catholic church). Under the Austrian rule they were consigned to graves in a cemetery outside the village, along the road from Lvov to Bóbrka. These cemeteries hosted also the inhabitants of the adjacent villages, parishioners of the Roman Catholic church in Dawidów. Few gravestones commemorating Poles have survived to our times. After WWII, the crosses with plaques disappeared from the cemetery together with a large number of gravestones with Polish inscriptions.

Nadesłany 2 VII 2020

Po poprawkach recenzyjnych 24 I 2021

Zaakceptowany 25 I 2021

Prof. dr hab. Ryszard Tomczyk

Instytut Historyczny Uniwersytetu Szczecińskiego

ul. Krakowska 71-79

71-017 Szczecin

rtomczyk10@wp.pl 

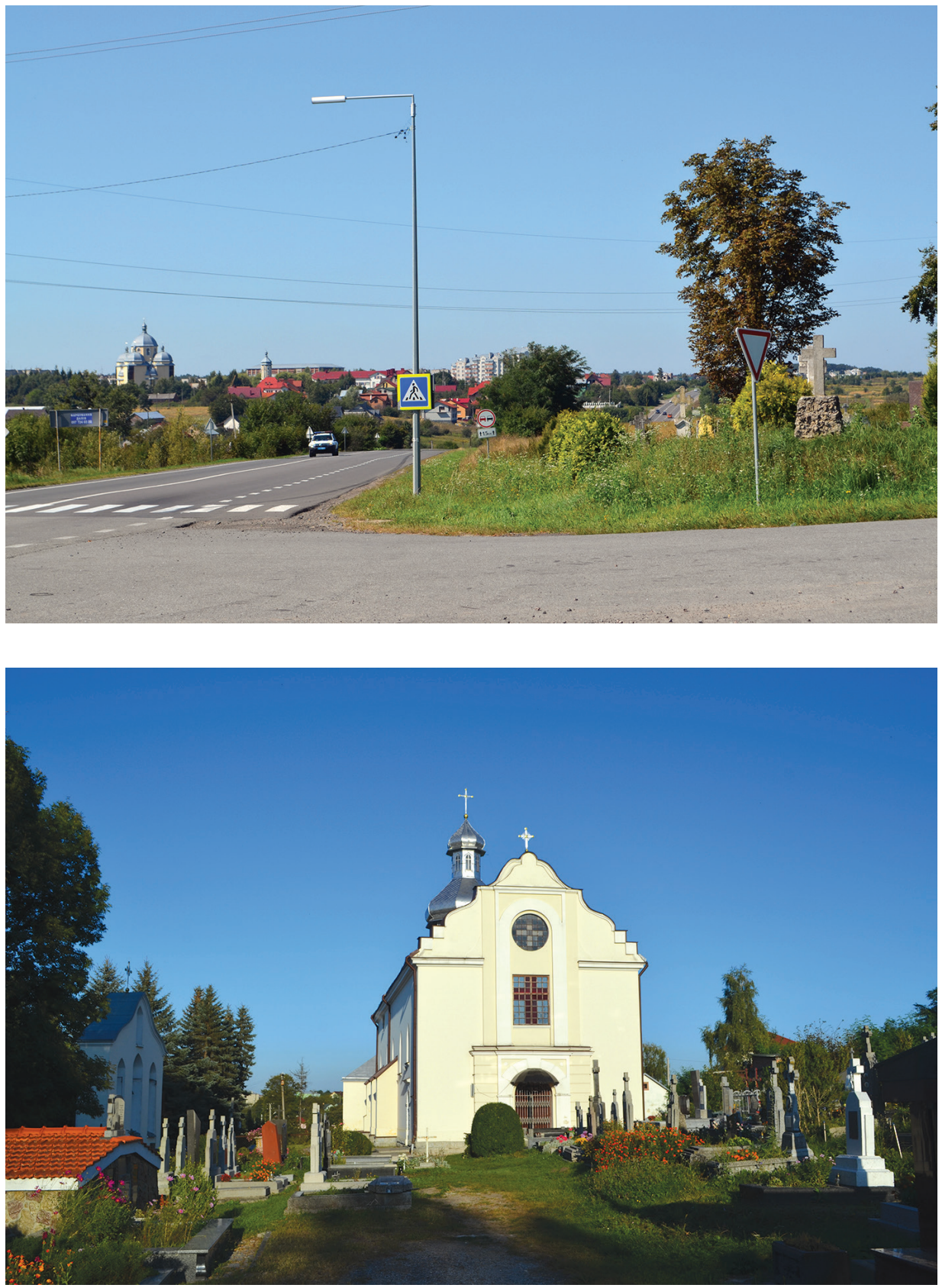


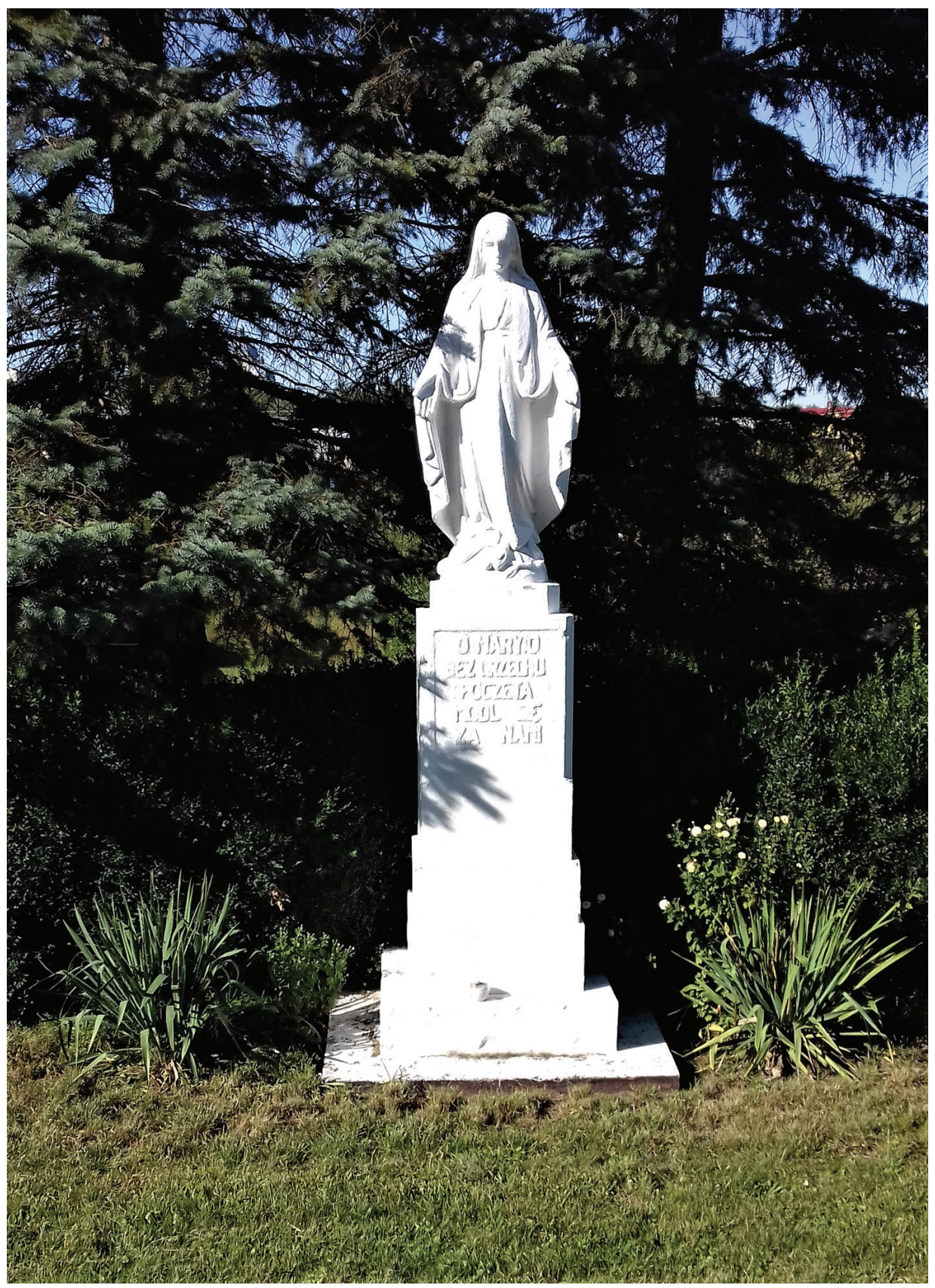




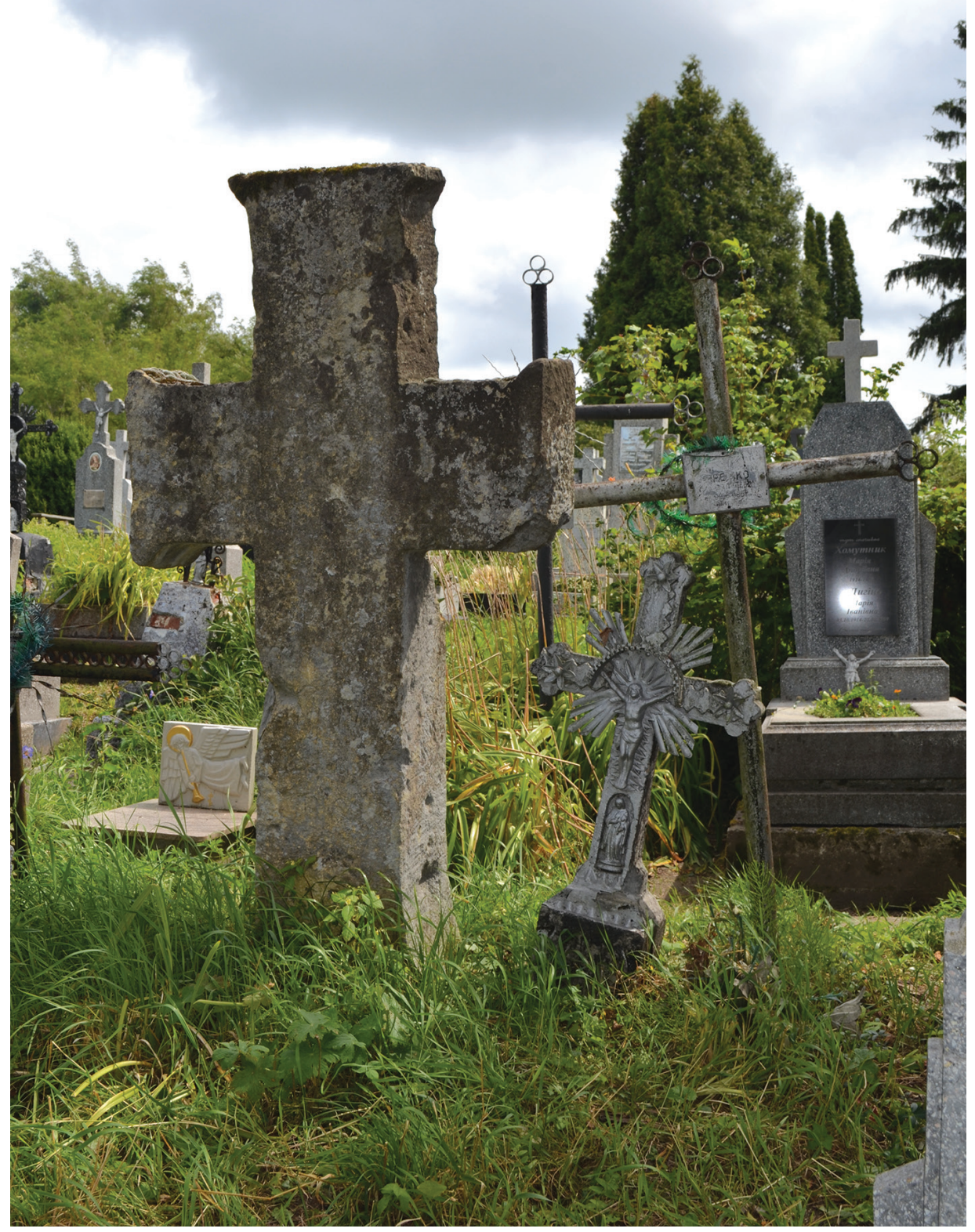



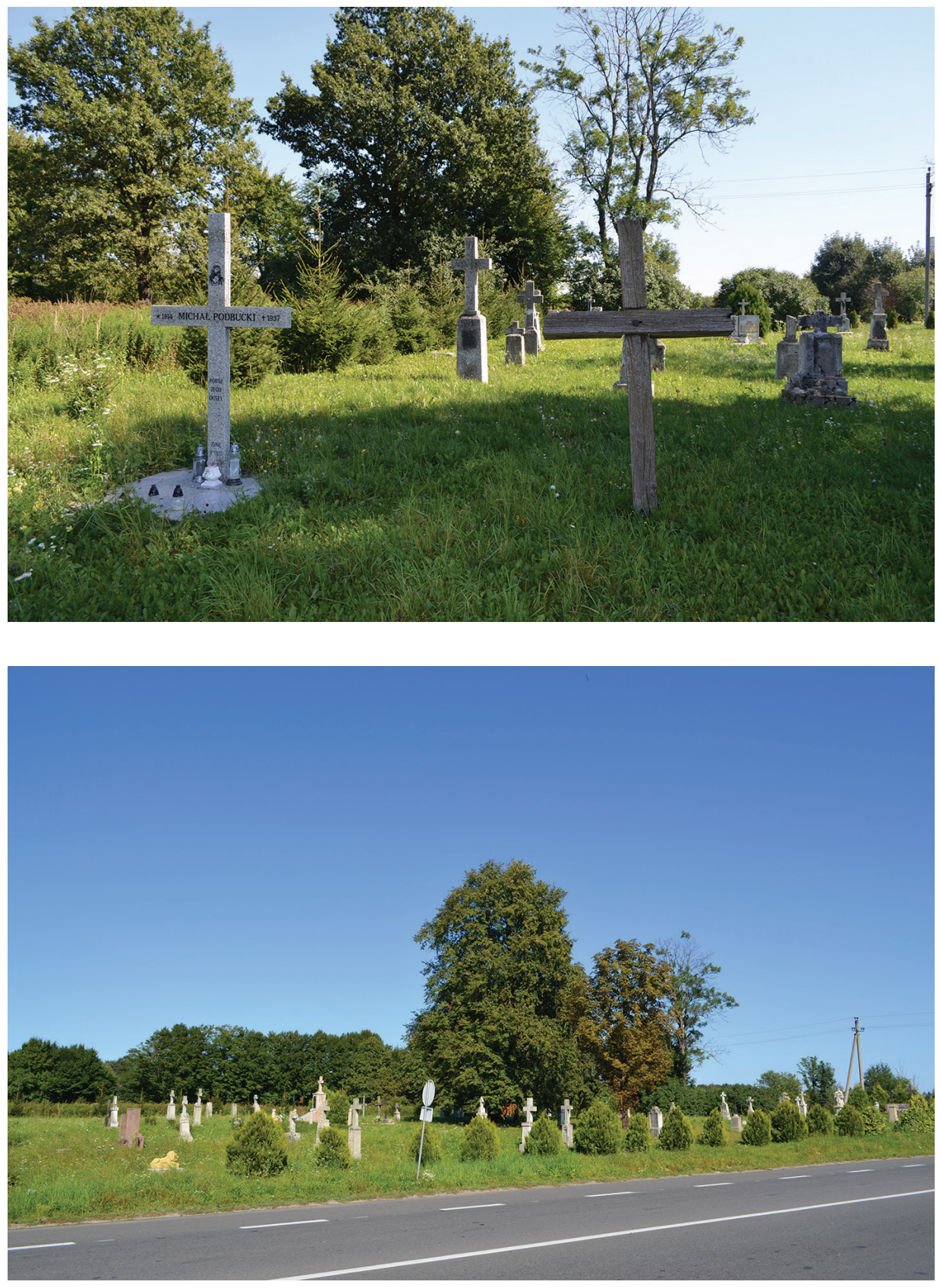


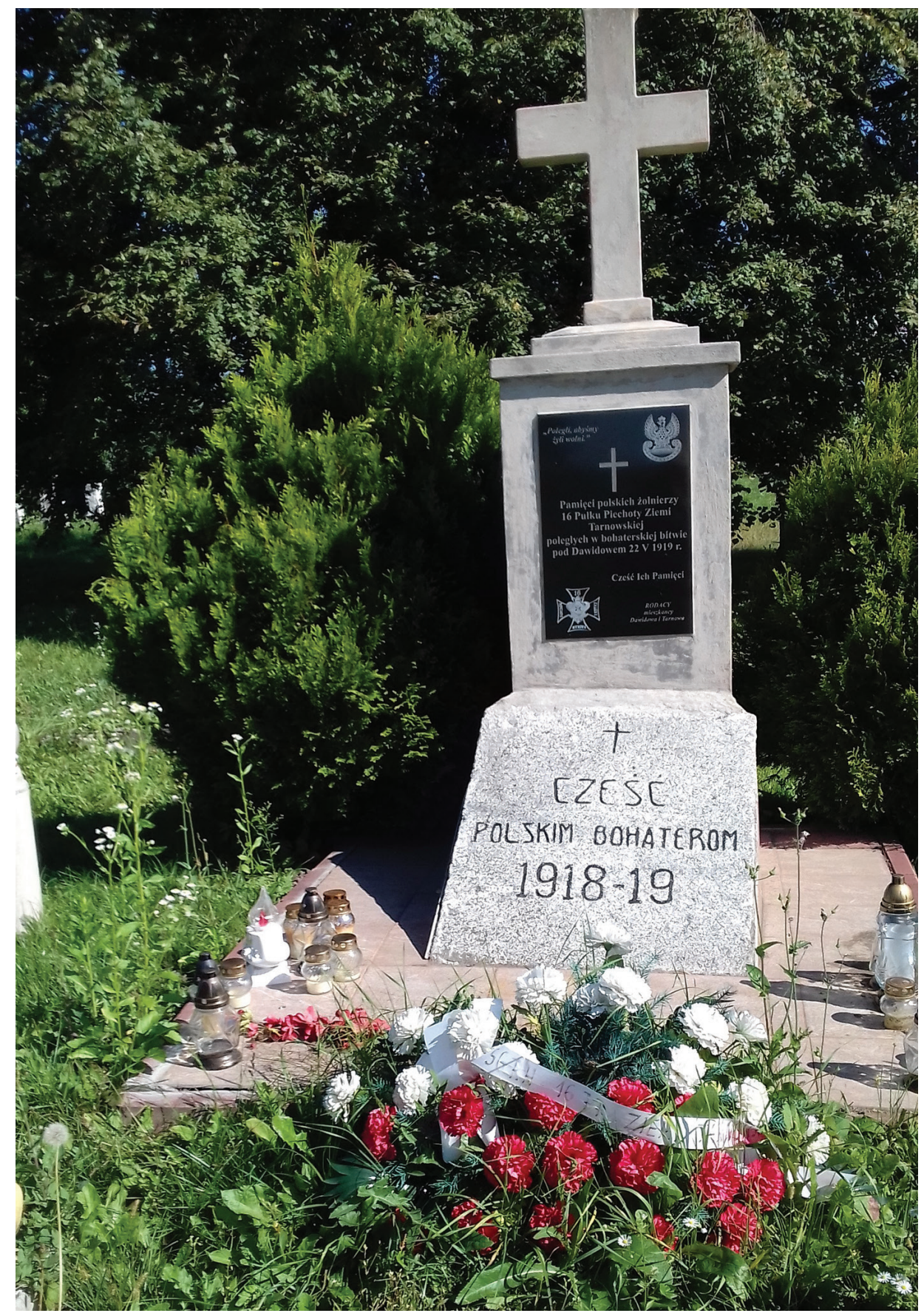




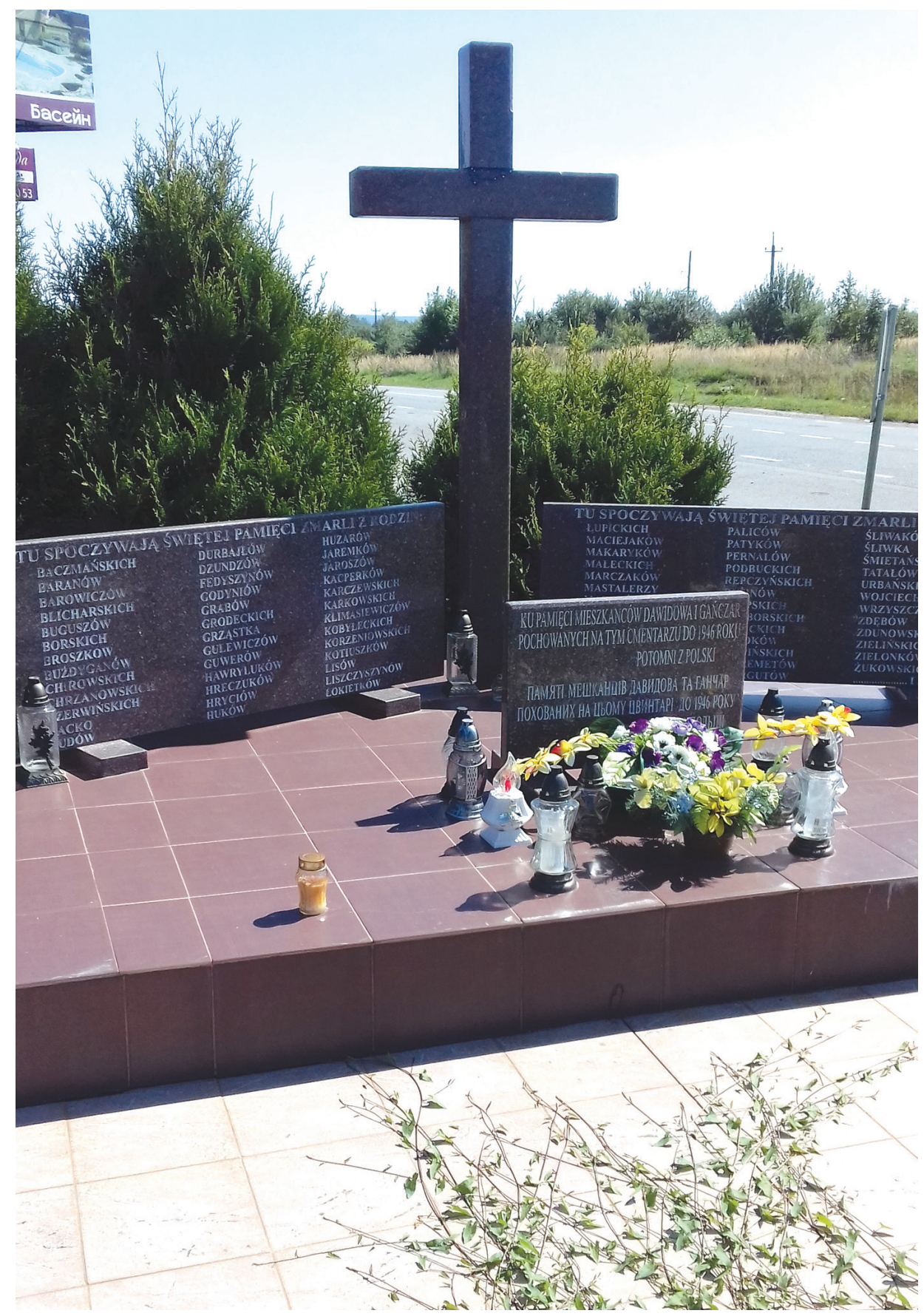

